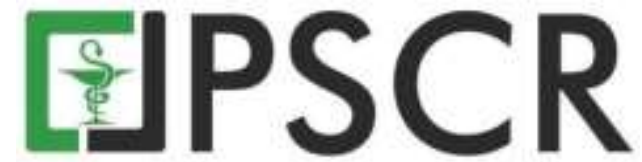

\title{
Isolasi Sinensetin dari Kumis Kucing (Orthosiphon aristatus Blume miq.) Varietas Putih
}

\author{
Fahrauk Faramayuda ${ }^{1,2^{*}}$, Soraya Riyanti², Adella Shindy Pratiwi², Totik Sri Mariani ${ }^{3}$, \\ Elfahmi $^{1,4}$ dan Sukrasno ${ }^{1}$
}

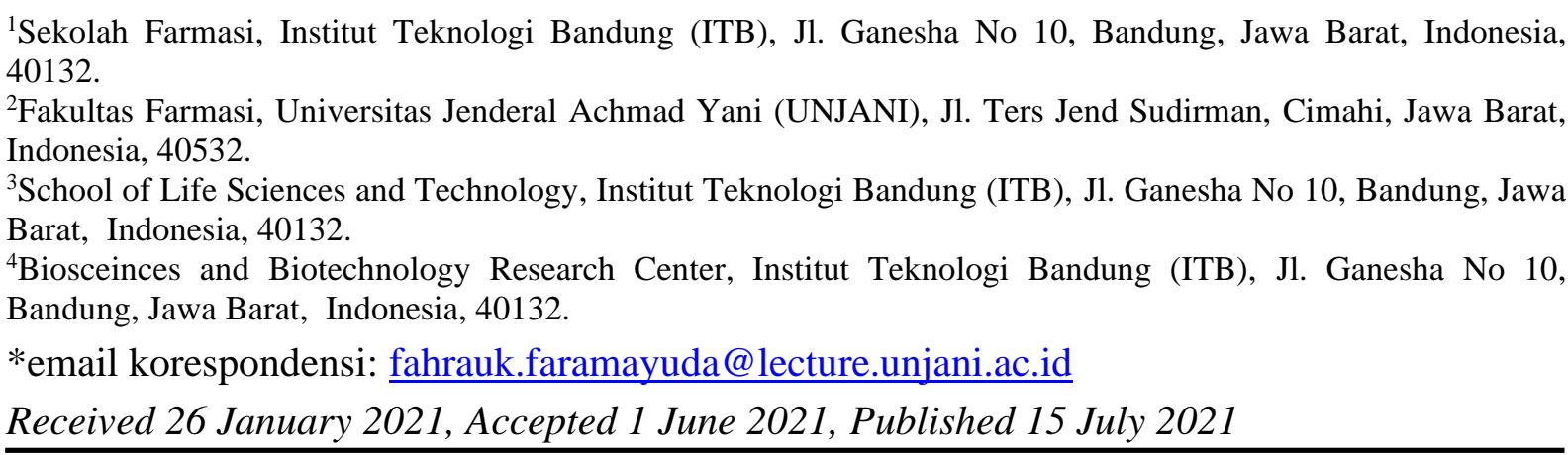

Abstrak: Kumis kucing mengandung metabolit sekunder sinensetin yang termasuk ke dalam golongan senyawa flavonoid. Sinensetin berpotensi sebagai agen antivirus dan imunomodulator. Tujuan penelitian ini adalah standardisasi tanaman kumis kucing varietas putih dan upaya produksi senyawa sinensetin. Ekstraksi dilakukan dengan metoda maserasi. Tahap pemisahan lanjutan dilakukan dengan metoda ekstraksi cair-cair, kromatografi kolom dan kromatografi cair vakum. Hasil ekstraksi cair-cair terpilih tiga fraksi yaitu fraksi air, etil asetat dan n-heksana. Sebanyak 2,08 gram fraksi etil asetat dilanjutkkan pada tahap pemisahan lanjutan menggunakan kromatografi cair vakum dengan fasa diam silika gel H60 dan fasa gerak n-heksana dan etil asetat. Hasil dari kromatografi cair vakum diperoleh sebanyak 11 subfraksi. Penggabungan dilakukan pada subfraksi 8-11 yang terdeteksi adanya senyawa sinensetin, selanjutnya terhadap subfraksi gabungan dilakukan pemisaahan lanjutan dengan kromatografi kolom. Hasil pemisahan dengan kromatografi kolom diperoleh subfraksi sebanyak 142 vial. Pada subfraksi hasil kromatografi kolom nomor 91-114 terdeteksi adanya isolat sinensetin. Kromatografi lapis tipis preparatif (KLTP) gabungan subfraksi kromatografi kolom 91-114 (SFK) menunjukkan adanya senyawa sinensetin. Berdasarkan hasil pemeriksaan kemurnian dengan menggunakan KLT 2 dimensi dan analisis profil spektrum UV isolat diduga senyawa sinensetin.

Kata kunci: Kumis kucing; sinensetin; kromatografi cair vakum; kromatografi kolom; identifikasi senyawa aktif

Abstract: Isolation of sinensetin from cat's whiskers (Orthosiphon aristatus Blume miq.) white variety. Cat's whiskers contain a secondary metabolite sinensetin which belongs to the class of flavonoid compounds. Sinensetin has the potential as an antiviral and immunomodulatory agent. The purpose of this research was the standardization of white variety cat whiskers and the production of sinensetin compounds. Extraction was carried out by the maceration method using $96 \%$ ethanol as solvent. The further separation step was carried out by liquid-liquid extraction, vacuum liquid chromatography, and column chromatography. The results of the liquid-liquid extraction were selected from three fractions, namely water, ethyl acetate, and n-hexane fractions. A total 2.08 gram of ethyl acetate fraction was continued in a further separation step using vacuum liquid chromatography with silica gel H60 as a stationary phase and n-hexane and ethyl acetate as mobile phases. The results of vacuum liquid chromatography obtained as many as 11 subfractions. The amalgamation was carried out on subfractions 8-11 which detected the presence of sinensetin compounds, then 
the combined subfractions were further separated by column chromatography. The results of column chromatography separation obtained subfraction of as many as 142 vials. In the subfraction of column chromatography results in numbers $91-114$, sinensetin isolates were detected. Preparative thin-layer chromatography combined with column chromatography subfraction 91-114 (SFK) showed the presence of sinensetin compounds. Based on the results of the purity examination using 2-dimensional TLC and analysis of the UV spectrum profile of the isolate, it was suspected that sinensetin was a compound.

Keywords: Cat's whiskers; sinensetin; extraction; fractionation; vacuum liquid chromatography; column chromatography; identification of active compounds

\section{Pendahuluan}

Kumis kucing adalah tanaman obat tradisional yang sudah banyak digunakan secara empiris di beberapa wilayah asia dan eropa. Hasil penelitian sudah banyak melaporkan aktivitas farmakologi dari kumis kucing, diantaranya adalah diuretik (Olah et al., 2003; Arafat et al., 2008; Adam et al., 2009), analgesik dan antipiretik (M. Yam et al., 2008), antihipertensi (Matsubara et al., 1999), efek hepatoprotektif (M. Yam et al., 2007; Maheswari et al., 2008), pencegahan dan pengobatan kanker (Pauzi et al., 2018; Halim et al., 2017), antivirus (Ripim et al., 2018).

Pada masa pandemi Covid-19 penemuan senyawa atau tanaman obat tradisional yang berpotensi sebagai antivirus dan imunomodulator terus dilakukan dan berdasarkan hasil penelitian senyawa yang terkandung dalam tanaman kumis kucing berpotensi sebagai inhibitor Covid-19 (Sarkar \& Das ; 2020; Rowaiye et al., 2020; Sekiou et al., 2020; Adem et al., 2020; Dahab et al., 2020; Narkhede et al., 2020; Sharma \& Kaur, 2020; Faramayuda et al., 2021), antiherpetik (Ikeda et al., 2011; Medini et al., 2016; Astani et al., 2011; Astani \& Schnitzler, 2014; Bourne et al., 1999; Benencia \& Courreges, 2000; Sharifi-Rad et al., 2018), anti-human immunodeficiency virus (HIV) (Lin et al., 1999; McDougall et al., 1998; Zhang et al., 2014; Mengoni et al., 2002; Kashiwada et al., 1998; Xu et al., 1996), anti hepatitis (Haid et al., 2012; Duan et al., 2016; Kong et al., 2013; Chang et al., 2016) dan imunomodulator (Harun et al., 2015; Woottisin et al., 2011; Friedman, 2015; Kim et al., 2008; Takano et al., 2004; Sanbongi et al., 2004; Youn et al., 2003).

Uji klinis terhadap manusia dari tanaman kumis kucing telah dilaporkan dan menunjukkan hasil yang baik (Premgamone et al., 2001; Adnyana et al., 2013). Uji toksisitas yang menjamin tingkat keamanan dari kumis kucing telah dilaporkan, diantaranya studi toksisitas ekstrak air terstandar kumis kucing pada dosis 250, 500, 1000 dan $2000 \mathrm{mg} / \mathrm{kg}$ $\mathrm{BB} /$ hari, selama pemberian 60 hari pada tikus jantan tidak menunjukkan tanda-tanda toksisitas (Muhammad et al., 2013). Ekstrak etanol 50\% terstandar kumis kucing dengan dosis 5000 $\mathrm{mg} / \mathrm{kg}$ diberikan secara oral kepada tikus betina Sprague Dawley (SD) tidak menunjukkan adanya kelainan pada organ dan gambaran histopatologi organ. Hasil ini diikuti oleh toksisitas 
subkronik dimana selama 28 hari pemberian ekstrak tidak berbeda signifikan dengan kelompok kontrol (E. Mohamed et al., 2010). Aktifitas farmakologi ini sangat tergantung pada kualitas bahan tanaman yang diujikan.

Standardisasi pada bahan baku tanaman perlu dilakukan untuk menjaga konsistensi kualitas produk obat tradisional yang dihasilkan. Parameter standardisasi simplisia meliputi parameter spesifik dan non spesifik. Parameter non spesifik meliputi penetapan susut pengeringan, penentuan kadar abu total dan penetapan kadar abu yang tidak larut asam, sedangkan penentuan kadar sari larut air, penentuan kadar sari larut etanol dan analisis kuantitatif senyawa marker merupakan parameter spesifik (Anonim, 2017; Maulana et al., 2020; Savitri et al., 2020).

Senyawa utama atau marker dalam kumis kucing adalah asam rosmarinat, danshensu, eupatorin dan sinensetin (Guo et al., 2019). Senyawa sinensetin termasuk ke dalam golongan senyawa flavon polimetoksi (Gambar 1). Senyawa flavon polimetoksi memiliki beberapa aktivitas dan merupakan bagian dari mekanisme pertahanan kimia tanaman (Berim \& Gang, 2016). Tanaman kumis kucing yang tumbuh di Indonesia ada tiga varietas yaitu kumis kucing berbunga putih, putih-ungu dan ungu (Febjislami et al., 2019). Perbedaan yang paling mendasar ketiga varietas tersebut adalah dari morfologi bunga (Keng \& Siong, 2006). Penelitian sebelumnya melaporkan bahwa sinensetin terdapat pada tiga varietas tersebut (Febjislami, 2017). Faktor yang berpengaruh pada kadar sinensetin dalam tanaman kumis kucing adalah usia, tingkat kematangan dan lokasi tumbuh. Berdasarkan usia dan tingkat kematangan yang sama, kadar sinensetin beberapa genotype kumis kucing varietas putih lebih tinggi dibandingkan varietas lainnya (Batubara et al., 2020). Penelitian identifikasi dan isolasi senyawa marker sinensetin pada tanaman kumis kucing varietas putih belum banyak dilaporkan.

Teknik isolasi menggunakan kromatografi kolom sephadex LH-20 dan KLT preparatif terhadap $100 \mathrm{mg}$ ekstrak etil asetat $C$. Reticulata menghasilkan 23,4 mg sinensetin (Nakanishi et al., 2019). Simplisia Kulit C. Reticulata sebanyak $500 \mathrm{~g}$ menghasilkan 38,8 mg sinensetin dengan menggunakan kromatografi kolom (Nagase et al., 2005). Isolasi sinensetin dari Citrus reticulata dengan menggunakan high-speed counter current chromatography (HSCCC) dan kromatografi cair kinerja tinggi preparatif menghasilkan 27,7 mg sinensetin (Du \& Chen, 2010). Teknik isolasi senyawa marker sinensetin yang lebih sederhana menggunakan kromatografi cair vakum perlu dilakukan sebagai alternatif metode isolasi. Sehingga tujuan penelitian ini yaitu merancang teknik isolasi dengan metoda kromatografi cair vakum. 


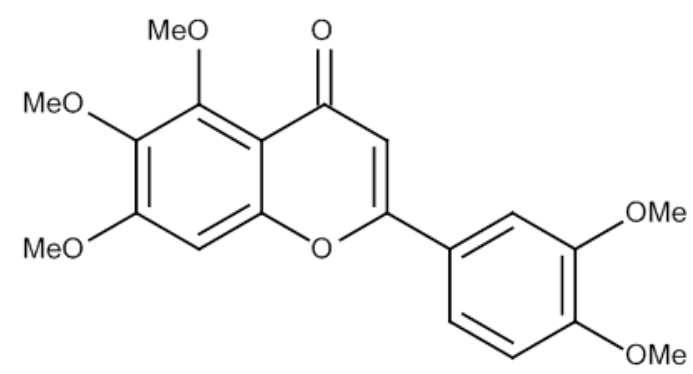

Gambar 1. Struktur senyawa sinensetin pada tanaman kumis kucing (Orthosiphon aristatus blume miq.).

\section{Bahan dan Metode}

\subsection{Bahan kimia dan reagen}

Sinensetin (Sigma St. Louis, MO, USA), etanol (Merck Jakarta, Indonesia), etil asetate (Merck Jakarta, Indonesia), n-heksana (Merck Jakarta, Indonesia), Pelat silika gel 60 F254 (Merck Jakarta, Indonesia), silika gel 60 F254, silika gel H60, kloroform, kloralhidrat, asam borat, asam sitrat dan aquadest.

\subsection{Peralatan}

Alat gelas yang umum digunakan di laboratorium, maserator, timbangan analitik (Shimadzu, Jepang), oven (Memert, Jerman), dan rotary evaporator (Heidolp, Jerman), kromatografi cair vakum (KCV) dan kromatografi kolom (KK).

\subsection{Prosedur penelitian}

2.3.1 Pengumpulan dan pengolahan bahan tanaman.

Tanaman kumis kucing varietas putih diperoleh dari Kebun Tanaman Obat Manoko, Lembang, Jawa Barat. Umur tanaman kumis kucing yang digunakan adalah sembilan bulan, pengambilan dilakukan pada bulan Februari tahun 2020. Kebun percobaan manoko berada pada ketinggian $1.200 \mathrm{mdpl}$ dengan curah hujan $1.756 \mathrm{~mm}$ dalam satu tahun, temperatur minimum $15.5{ }^{\circ} \mathrm{C}$ Kelembaban 85,12\% dan jenis tanah Andosol. Daun kumis kucing segar sebanyak 2,5 kg dicuci dengan air mengalir dan dikeringkan. Berat simplisia yang didapat adalah $1,35 \mathrm{~kg}$. Determinasi tanaman dilakukan dengan mengirimkan sampel kepada Laboratorium taksonomi tumbuhan, Departemen Biologi FMIPA UNPAD.

\subsubsection{Penapisan fitokimia.}

Penapisan fitokimia meliputi identifikasi golongan steroid-triterpenoid, alkaloid, tanin, monoterpenoid-seskuiterpenoid, flavonoid, kuinon, saponin dan polifenol (Anonim, 2017).

\subsubsection{Standardisasi simplisia.}

Pemeriksaan karakterisasi simplisia meliputi kadar sari larut etanol, kadar air, kadar abu tidak larut asam, kadar abu larut air, kadar sari larut air dan kadar abu total (Anonim, 2017). 


\subsubsection{Isolasi sinensetin.}

- Ekstraksi daun kumis kucing

Serbuk simplisia daun kumis kucing sebanyak $200 \mathrm{~g}$ diekstraksi dengan maserasi menggunakan $1 \mathrm{~L}$ pelarut etanol $96 \%$ selama 24 jam, proses ekstraksi dilakukan 3 kali pengulangan. Terhadap maserat yang diperoleh dilakukan proses pemekatan menggunakan rotary evaporator pada suhu $50^{\circ} \mathrm{C}$ dan uapkan di atas penangas air untuk mendapatkan ekstrak kental. Ekstrak yang sudah pekat ditimbang dan dihitung \% rendemen.

\section{- $\quad$ Partisi daun kumis kucing}

Ekstrak kental sebanyak 24,834 g ditambahkan air 100 mL. Ekstrak air dimasukan ke dalam corong pisah dan dilakukan penambahan n-heksan dengan perbandingan 1:1. Setelah itu dikocok dan didiamkan hingga kedua pelarut terpisah sempurna, proses ini dilakukan sebanyak 3 kali. Lapisan air kembali dimasukkan ke dalam corong pisah untuk selanjutnya ditambahkan etil asetat (1:1) kemudian dikocok dan didiamkan hingga terpisah, diulangi hingga 3 kali. Lapisan air, etil asetat dan n-heksan diuapkan menggunakan rotary evaporator hingga mendapatkan fraksi kental. Dari ketiga fraksi yang diperoleh kemudian diuapkan dengan penangas air hingga menghasilkan fraksi kental.

2.3.5 Pemantauan profil fitokimia menggunakan metode Kromatografi Lapis Tipis (KLT).

Proses elusi KLT dilakukan menggunakan chamber kromatografi yang berisi fase gerak n-heksana : etil asetat (3:7), kloroform : etil asetat (60:40) dan fase diam silika gel GF254. Plat silika gel $\mathrm{GF}_{254}$ di potong dengan ukuran $2 \times 8,5 \mathrm{~cm}$, kemudian diberi jarak $1 \mathrm{~cm}$ pada bagian bawah yang digunakan untuk menotolkan sampel pembanding dari sinensetin dan $0,5 \mathrm{~cm}$ dibagian atas sebagai batas elusi. Setelah proses elusi selesai kemudian diamati dibawah UV $254 \mathrm{~nm}$ dan UV $366 \mathrm{~nm}$. Plat KLT kemudian disemprotkan pereaksi penampak bercak sitroborat yang spesifik untuk golongan flavonoid (Santosa dan Haresmita, 2015). Pereaksi sitroborat dibuat dengan cara menimbang 0,5 g asam sitrat dan $0,5 \mathrm{~g}$ asam borat dilarutkan dalam etanol $(50 \mathrm{~mL})$.

\subsubsection{Kromatografi Cair Vakum (KCV).}

Proses pemisahan lanjutan menggunakan kromatografi cair vakum (KCV). Silika gel H60 sebanyak 150 g dimasukkan kedalam kolom KCV dan bagian atas kolom dilapisi dengan kertas saring. Kemudian ekstrak pekat ditimbang sebanyak 1 gram dan dimasukkan ke dalam mortir serta ditambahkan sebagian silika gel H60 sebanyak 5 g. Proses elusi dilakukan menggunakan sistem elusi bertingkat dengan fasa gerak $\mathrm{n}$ heksan : etil asetat dengan perbandingan 100 : 0 sampai 0 : 100, volume dalam satu kali elusi adalah $100 \mathrm{~mL}$ Pada proses KCV menghasilkan 11 subfraksi. Subfraksi 8 dan 9 (SFA) serta 10 -11 (SFB) digabung 
karena memiliki pola profil KLT yang sama. Pemisahan lanjutan menggunakan kromatografi kolom dilakukan pada gabungan subfraksi 8-11 (3,25 gram), dimana pada fraksi tersebut terdeteksi adanya senyawa sinensetin. Sistem fasa gerak sama dengan sistem pada KCV. Subfraksi yang memiliki pola bercak yang sama kemudian digabung. Hasil kromatografi kolom mendapatkan 142 subfraksi kolom (SFK). Pada rentang SFK 91 - 124 terdeteksi adanya senyawa sinensetin. Dari hasil penggabungan SFK dihasilkan beberapa sampel yaitu SFKA (SFK 91,94,98,103,108,109,110,112,114), SFKB (SFK 115,116,118,119), SFKC (SFK 120-123) dan SFKD (SFK 124).

\subsubsection{Pemisahan lanjutan dengan Kromatografi Lapis Tipis Preparatif (KLTP).}

Analisis dengan KLTP diawali dengan menyiapkan plat silika $\mathrm{GF}_{254}$ sebagai fase diam, proses pembuatan plat dengan membuat silika gel $60 \mathrm{~F}_{254}$ sebanyak 25 gram dalam $50 \mathrm{~mL}$ aquadest (1:2) kemudian dikocok hingga homogen kemudian tuangkan pada plat kaca berukuran $20 \times 20 \mathrm{~cm}$. Fasa gerak yang digunakan adalah n-heksan : etil asetat (3:7). Aplikasikan SFK A sebanyak $60,5 \mathrm{mg}$ pada plat sehingga membentuk pita yang dilihat di bawah lampu UV $365 \mathrm{~nm}$. Pita yang teramati kemudian dipisahkan dan ditambahkan pelarut etil asetat untuk selanjutnya diidentifikasi menggunakan KLT

\subsubsection{Uji kemurnian.}

Uji kemurnian dilakukan dengan metode KLT 2 dimensi. Isolat yang telah diperoleh kemudian ditotolkan pada plat KLT dengan ukuran 10x10 cm, kemudian dielusi menggunakan pelarut yang sesuai. Pada saat elusi yang pertama selesai, selanjutnya plat diputar $90^{\circ}$ berlawanan arah jarum jam. Setelah proses elusi yang kedua selesai kemudian diamati dibawah lampu UV $254 \mathrm{~nm}$ dan UV $365 \mathrm{~nm}$.

\subsubsection{Identifikasi isolat dengan Spektrofotometri UV-Vis.}

Identifikasi isolat dengan menggunakan instrumen spektrofotometri $U v$-Visible untuk mengetahui panjang gelombang dari isolat dan dibandingkan dengan standar sinensetin $(324,1$ $\mathrm{nm}$ ). Sampel dilarutkan dalam pelarut metanol. Kemudian dicatat hasil absorbansi dan spektrum dari sampel yang digunakan.

\section{Hasil dan Pembahasan}

Hasil determinasi bahan tanaman yang dilakukan di laboratorium taksonomi tumbuhan, Departemen Biologi FMIPA UNPAD dengan nomor surat No.20/HB/09/2020 menjelaskan bahwa jenis tanaman yang diteliti mempunyai nama Ilmiah Orthosiphon aristatus, sinonim Orthosiphon stamineus Benth, nama lokal kumis kucing, famili Lamiaceae.

Perbedaan paling mendasar antara kumis kucing varietas ungu dan putih, yaitu pada morfologi bunganya, terutama warna mahkotanya (Keng \& Siong, 2006). Pada varietas putih 
warna mahkota berwarna putih, sedangkan pada varietas ungu warna mahkota ungu (Gambar 2).

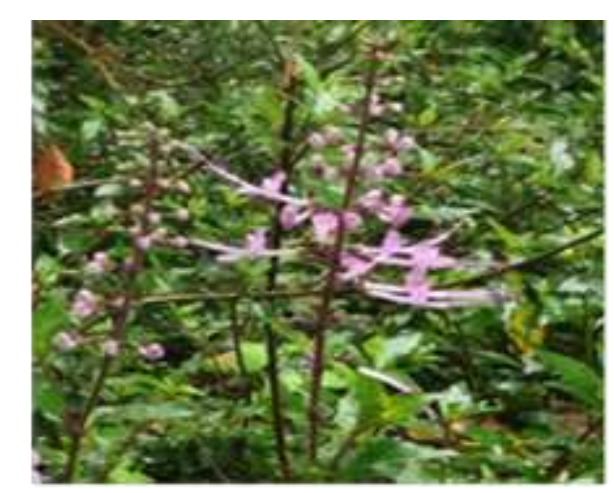

(a)

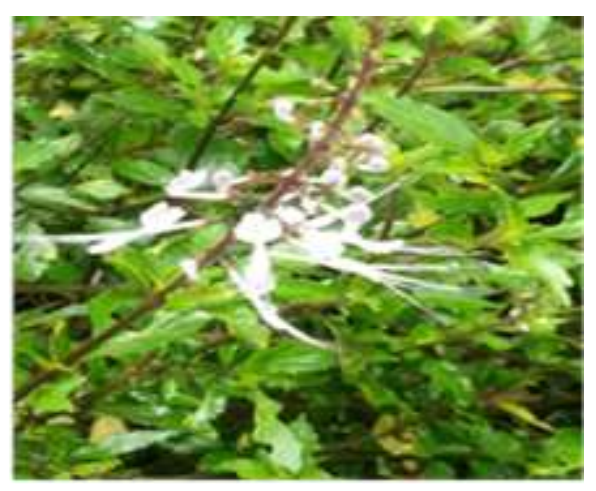

(b)

Gambar 2. Tanaman kumis kucing. kumis kucing varietas ungu (a) dan kumis kucing varietas putih (b).

Pengamatan mikroskopik sayatan membujur daun kumis kucing dengan menggunakan pelarut kloralhidrat dan perbesaran menunjukkan adanya rambut penutup, stomata tipe diasitik dan epidermis bawah dengan rambut penutup (Gambar 3). Menurut Farmakope Herbal Indonesia (FHI) edisi II fragmen spesifik dari tanaman kumis kucing adalah epidermis bawah dengan stomata, rambut sisik dan berkas pengangkut tipe spiral, rambut penutup dan epidermis atas dengan rambut penutup (Anonim, 2017).

Bahan baku daun kumis kucing varietas putih diperoleh dari kebun percobaan Manoko Lembang Kabupaten Bandung Barat. Waktu pengambilan sampel pada Februari 2019. Sebanyak 1000 gram bahan segar kumis kucing varietas putih diambil dan kemudian dikeringkan dalam lemari pengering dengan suhu $60^{\circ} \mathrm{C}$. Hasil simplisia kering sebanyak 525 gram.

Hasil penapisan fitokimia dari simplisia dan ekstrak etanol kumis kucing varietas putih mengandung senyawa golongan monoterpenoid-seskuiterpenoid flavonoid, tanin, saponin, polifenol, kuinondan steroid-triterpenoid (Tabel 1). Hasil penapisan fitokimia sejalan dengan yang dilaporkan Guo et al. pada tahun 2019, dimana tanaman kumis kucing mengandung golongan senyawa asam fenolik, flavonoid, diterpen dan asam lemak (Guo et al., 2019). Hasil penelitian lainnya melaporkan golongan metabolit sekunder yang ada pada tanaman kumis kucing varietas ungu dan putih-ungu adalah polifenol, flavonoid, alkaloid, monoterpenoid dan seskuiterpenoid, tanin, saponin, steroid dan triterpenoid, (Faramayuda et al, 2020), dari laporan tersebut terdapat perbedaan dimana hasil penapisan fitokimia pada penelitian ini tidak menunjukkan adanya golongan alkaloid. Berdasarkan hasil penelitian yang dilakukan oleh Guo (2019) tidak dilaporkan adanya golongan alkaloid pada daun kumis kucing. Penapisan fitokimia bertujuan untuk mengetahui golongan metabolit sekunder dari suatu sampel. Hasil 
penapisan menunjukkan adanya golongan senyawa flavonoid yang merupakan inti struktur dari senyawa sinensetin.
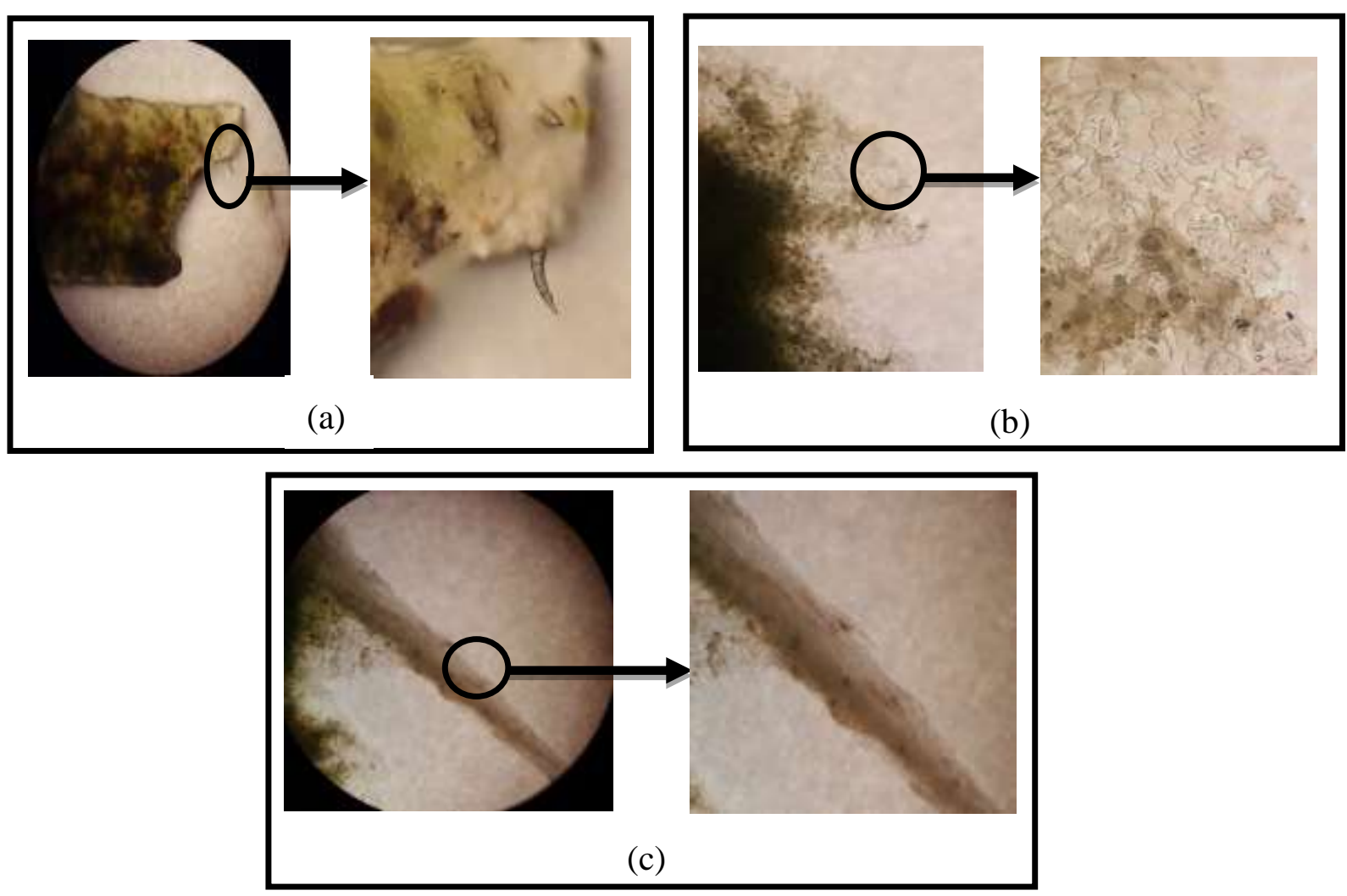

Gambar 3. Analisis mikroskopik daun kumis kucing. (a) rambut penutup, (b) stomata tipe diasitik dan (c) epidermis bawah dengan rambut penutup.

Tabel 1. Hasil penapisan fitokimia simplisia dan ekstrak tanaman kumis kucing varietas putih. $(-)=$ Tidak terdeteksi golongan senyawa metabolit sekunder yang diuji, $(+)=$ Terdeteksi golongan senyawa metabolit sekunder yang diuji.

\begin{tabular}{lcc}
\hline \multicolumn{1}{c}{ Metabolit Sekunder } & Simplisia & Ekstrak \\
\hline Alkaloid & - & - \\
Flavonoid & + & + \\
Saponin & + & + \\
Polifenol & + & + \\
Kuinon & + & + \\
Tanin & + & + \\
Monoterpenoid-Seskuiterpenoid & + & + \\
Steroid-Triterpenoid & + & + \\
\hline
\end{tabular}

Pemeriksaan karakterisasi simplisa bertujuan untuk menstandardisasi bahan baku yang akan dikembangkan menjadi tanaman obat tradisional dan pada akhirnya akan menjaga konsistensi kualitas, efektifitas serta keamanan obat tradisional. Hasil karakterisasi simplisia tanaman kumis kucing varietas putih dapat dilihat pada Tabel 2. Berdasarkan standar yang tercantum dalam Farmakope Herbal Indonesia (FHI) Edisi II nilai parameter karakterisasi simplisia kadar abu total dan tidak larut asam simplisia tanaman kumis kucing belum memenuhi persyaratan, hal ini bisa disebabkan karena pengaruh lokasi tumbuh seperti 
kandungan mineral dalam tanah dan air. kadar abu total meliputi abu fisiologis dan abu yang berasal dari cemaran polusi udara, tanah dan air. Abu tak larut asam menunjukkan adanya silika, dan abu larut air menunjukkan abu yang berasal dari garam larut air ( $\mathrm{Na}$ dan $\mathrm{Mg}$ ). Hasil penetapan kadar sari larut air, etanol dan kadar air memenuhi syarat dalam FHI edisi II (Anonim, 2017).

Maserasi merupakan ekstraksi cara dingin sehingga senyawa diharapkan tidak rusak dengan adanya pemanasan dan dilakukan dengan proses yang mudah serta sederhana. Simplisia yang diekstraksi sebanyak 200 g dalam 3 L etanol 96\%, ekstrak yang diperoleh kemudian dipekatkan menggunakan rotary evaporator dan diuapkan hingga memperoleh ekstrak kental. Ekstrak kental yang diperoleh sebaanyak 26,835 g dan persen rendemen sebanyak $13,417 \% \mathrm{~b} / \mathrm{b}$.

Rendemen fraksi yang diperoleh dapat dilihat pada Tabel 3. Fraksi n-heksan menghasilkan rendemen yang paling tinggi dibandingkan fraksi lainnya, hasil ini menunjukkan bahwa sebaran senyawa yang bersifat non polar lebih banyak.

Profil KLT dari tiga Fraksi dengan fasa gerak n-heksan : etil asetat (3:7) terdeteksi adanya senyawa sinensetin pada fraksi etil asetat dan $n$-heksan pada retention factor (Rf) 0,4 (Gambar4), sedangkan dengan fasa gerak kloroform : etil asetat (6:4) sinensetin terdeteksi pada fraksi etil asetat dan n-heksan dengan Rf 0,41. Sinensetin termasuk golongan senyawa flavon polimetoksi adanya gugus metoksi membuat senyawa ini bersifat semi polar dan cenderung mengarah non polar (Pang et al., 2014), oleh karena itu sinensetin terdeteksi pada fraksi etil asetat dan n-heksana.

Tabel 2. Hasil penapisan fitokimia simplisia dan ekstrak tanaman kumis kucing varietas putih.

\begin{tabular}{lcc}
\hline \multicolumn{1}{c}{$\begin{array}{c}\text { Parameter } \\
\text { Pemeriksaan }\end{array}$} & Hasil & $\begin{array}{c}\text { Standar nilai rujukan } \\
\text { (FHI Edisi II) }\end{array}$ \\
\hline Kadar Abu Total & $10,576 \pm 0,3608 \%(\mathrm{~b} / \mathrm{b})$ & $\leq 10,2 \% \mathrm{~b} / \mathrm{b}$ \\
Kadar Abu Tidak Larut & $9,712 \pm 0,0385 \%(\mathrm{~b} / \mathrm{b})$ & $\leq 3,4 \% \mathrm{~b} / \mathrm{b}$ \\
Asam & & - \\
Kadar Abu Larut Air & $4,262 \pm 0,0698 \%(\mathrm{~b} / \mathrm{b})$ & $\geq 7,2 \% \mathrm{~b} / \mathrm{b}$ \\
Kadar Sari Larut Etanol & $11,882 \pm 0,3152 \%(\mathrm{~b} / \mathrm{b})$ & $\leq 10 \% \mathrm{v} / \mathrm{b}$ \\
Kadar Air & $4,998 \pm 0,4892 \%(\mathrm{v} / \mathrm{b})$ & $\geq 10,2 \% \mathrm{~b} / \mathrm{b}$ \\
Kadar Sari Larut Air & $12,044 \pm 0,5719 \%(\mathrm{~b} / \mathrm{b})$ & \\
\hline
\end{tabular}

Fraksi etil asetat merupakan fraksi terpilih yang akan dilanjutkan pada tahap pemisahan lanjutan menggunakan kromatografi cair vakum (KCV). Sinensetin lebih berfluoresensi pada fraksi etil asetat dibandingkan dengan fraksi n-heksan. Beberapa laporan penelitian tentang ekstraksi dan penetapan kadar kumis kucing diantaranya adalah pemantauan profil KLT varietas kumis kucing dengan fase gerak kloroform - etil asetat (60:40), dimana sinensetin 
terdeteksi pada pada Rf 0,49 (Hossain \& Ismail, 2016), laporan tersebut tidak berbeda jauh dengan hasil penelitian dimana $\mathrm{Rf}$ senyawa sinensetin terdeteksi pada $\mathrm{Rf} 0,41$.

Tabel 3. Hasil rendemen fraksi air, etil asetat dan n-heksan kumis kucing varietas putih.

\begin{tabular}{ccc}
\hline Fraksi & Berat Fraksi (g) & Rendemen (\%) \\
\hline Air & 2,945 & 11,858 \\
Etil asetat & 7,586 & 30,548 \\
n-heksana & 12,544 & 50,511 \\
\hline
\end{tabular}

A

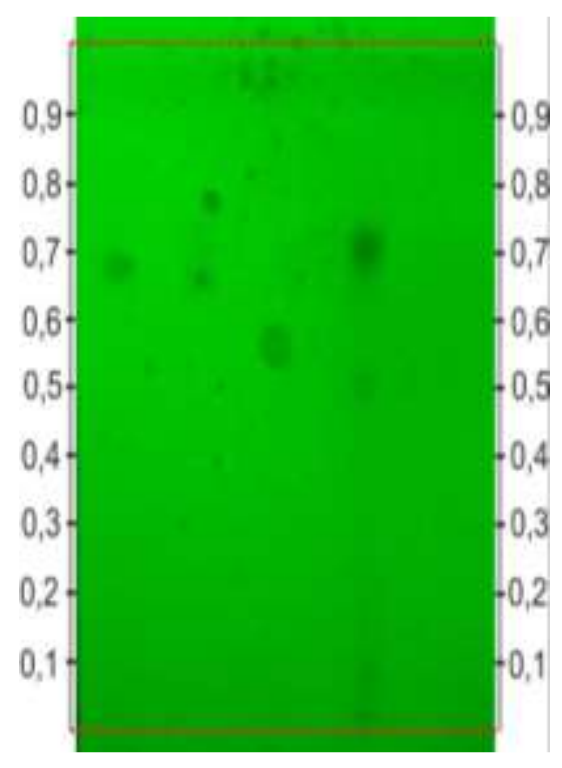

a $\quad b \quad c \quad d$
B

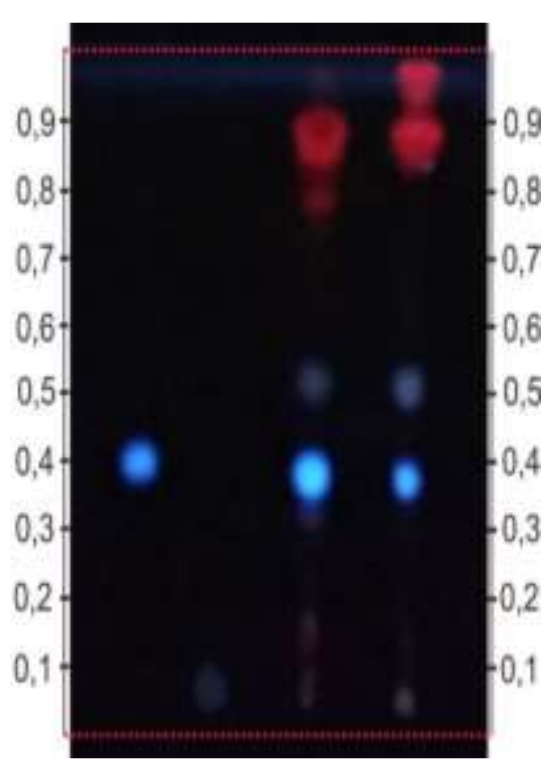

a $\quad$ b $\quad c \quad c \quad d$

Gambar 4. Profil KLT Fraksi air, etil asetat dan n-heksan kumis kucing pada fasa gerak nheksan : etil asetat (3:7). (A) lampu UV $254 \mathrm{~nm}$, (B) $365 \mathrm{~nm}$, (a) standar sinensetin, (b) fraksi air, (c) fraksi etil asetat dan (d) fraksi n-heksana.

Hasil KCV fraksi etil asetat menghasilkan 11 subfraksi, namun yang terdeteksi adanya senyawa sinensetin ada pada subfraksi 8 - 11 dengan nilai Rf 0.68 (Gambar 5). Pemisahan lanjutan dilakukan kembali dengan menggunakan kromatografi kolom dengan sistem fasa gerak gradien n-heksan : etil asetat. Sampel yang digunakan untuk kromatografi kolom adalah gabungan subfraksi 8-11. penggabungan kedua subfraksi tersebut didasarkan kesamaan profil KLT. Dari hasil kromatografi kolom dihasilkan 142 subfraksi kolom (SFK). Pada rentang SFK 91 - 124 terdeteksi adanya senyawa sinensetin, sedangkan SFK yang lainnya tidak terdeteksi adanya senyawa sinensetin. Pada SFK 91 - 124 yang mempunyai profil KLT yang sama digabungkan dan dilakukan pemantauan KLT kembali. Dari hasil penggabungan SFK dihasilkan beberapa sampel yaitu SFKA (SFK 91,94,98,103,108,109,110,112,114), SFKB (SFK 115,116,118,119), SFKC ( SFK 120-123) dan SFKD (SFK 124). 


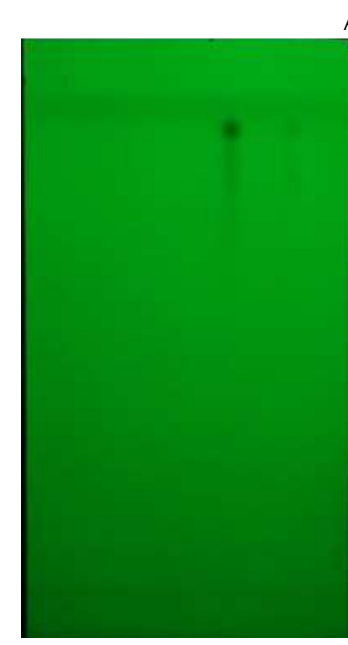

$\begin{array}{llll}3 & 4 & 5 & 6\end{array}$

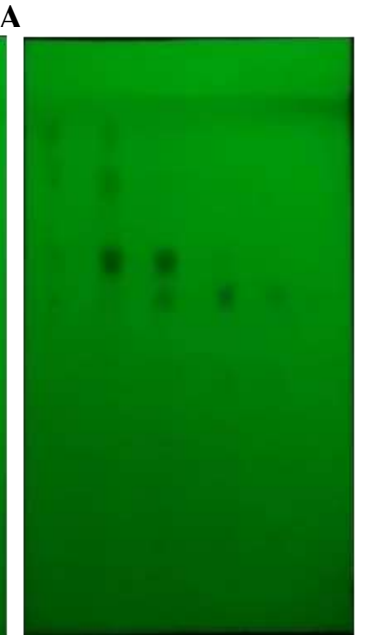

$\begin{array}{lllllll}7 & 8 & 9 & 10 & 11 & \mathrm{~S}\end{array}$

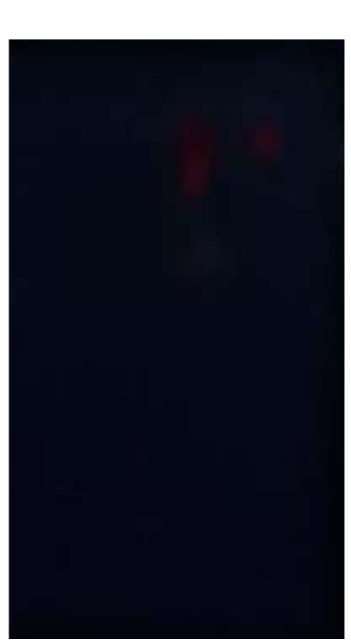

$\begin{array}{lllllllllll}3 & 4 & 5 & 6 & 7 & 8 & 9 & 10 & 11 & \mathrm{~S}\end{array}$
B

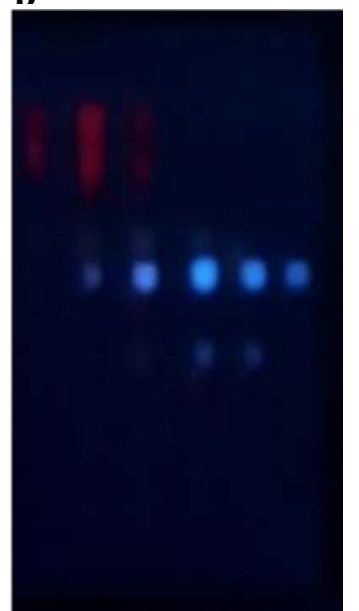

Gambar 5. Profil KLT subfraksi 3-11 hasil kromatografi cair vakum (KCV) dengan fasa gerak kloroform : etil asetat $6: 4$ (A) lampu UV $254 \mathrm{~nm}$ (B) $365 \mathrm{~nm}$.

Pemantauan KLT yang dilakukan terhadap SFK A - D dengan fasa gerak n-heksan : etil asetat (3:7), dari hasil gabungan subfraksi kolom tersebut senyawa sinensetin terdeteksi pada SFK A - D dengan Rf 0,5 (Gambar 6). SFK A menghasilkan fluoresensi yang terang dibandingkan dengan sub fraksi lainnya dan memiliki profil KLT yang baik, sehingga SFK A dilanjutkan pada tahap pemurnian menggunakan KLTP.

A

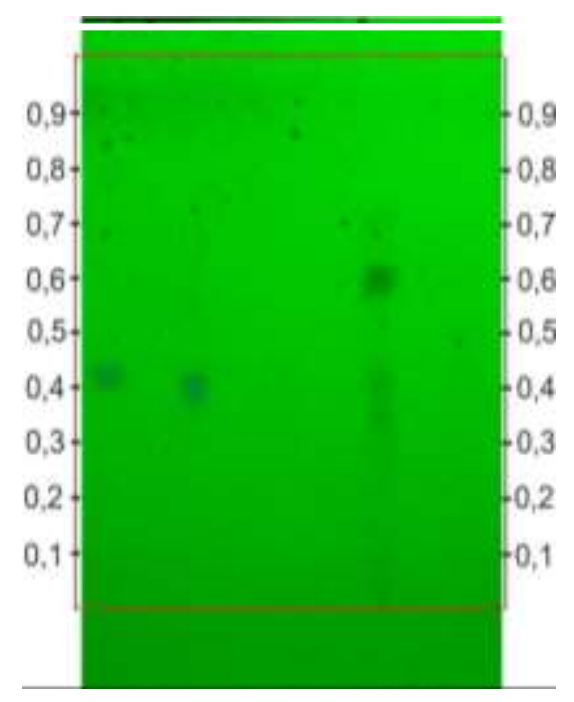

a $\quad$ b $\quad$ c $\quad$ d $\quad$ e

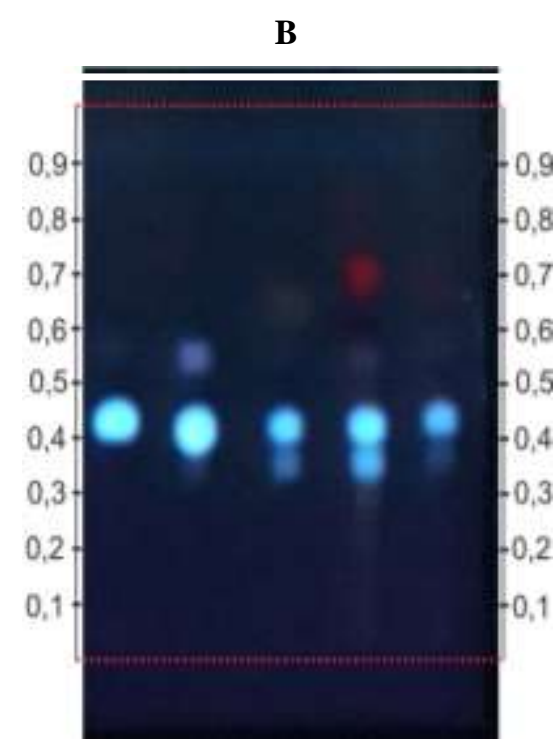

$\begin{array}{llllll}a & b & c & d & \text { e }\end{array}$

Gambar 6. Profil KLT gabungan subfraksi hasil kromatografi kolom (SFK) dengan fasa gerak n-heksan : etil asetat 3: 7 (A) lampu UV $254 \mathrm{~nm}$ (B) $365 \mathrm{~nm}$. (a) standar sinensetin, (b) SFK A, (c) SFK B, (d) SFK C, (e) SFK D

Analisa kemurnian terhadap isolat yang diperoleh menggunakan KLT 2D menunjukkan tetap muncul satu bercak dengan dua fasa gerak yang berbeda tingkat kepolarannya (Gambar 7). Identifikasi isolat dengan alat spektrofotometri UV-Vis menghasilkan pola spektrum 
dengan dua pita, dimana pita I memiliki panjang gelombang $328.6 \mathrm{~nm}$ dan pita II $264.2 \mathrm{~nm}$. Pola spektrum pada standar sinensetin teridentifikasi dua pita pula, panjang gelombang pada pita I 324,1 nm dan pita II 265,3 nm (Gambar 8). Adanya kemiripan profil spektrum isolat dan standar sinensetin, menunjukkan bahwa isolat diduga senyawa sinensetin.

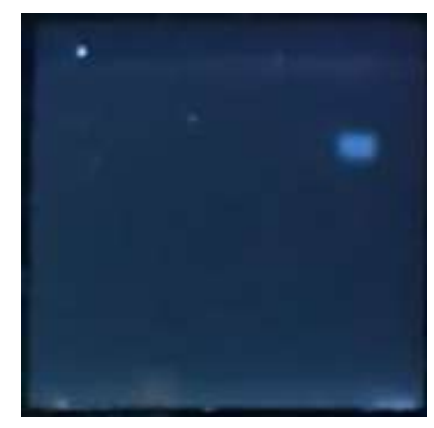

$\mathrm{a}$

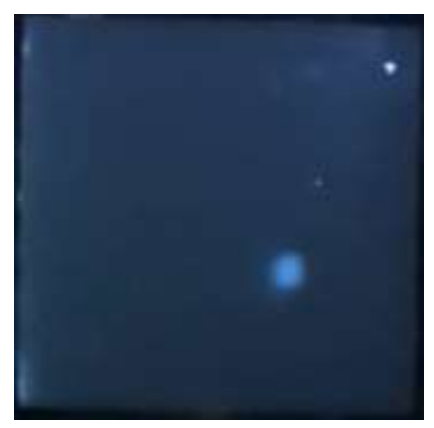

b

Gambar 7. Kromatogram KLT 2D Isolat. (a) Fasa gerak pertama n-heksana:etil asetat (3:7) dan (b) fasa gerak ke 2 n-heksana:etil asetat (7:3)

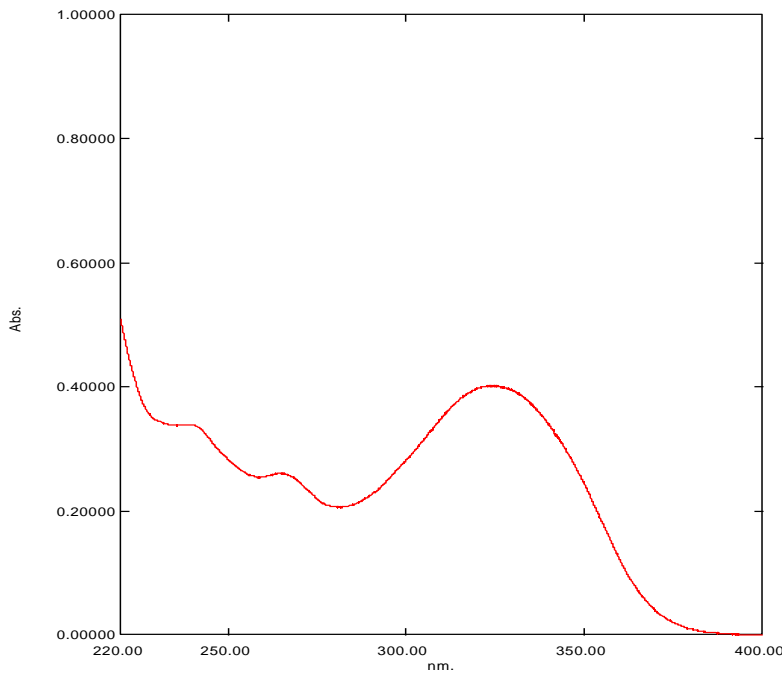

a

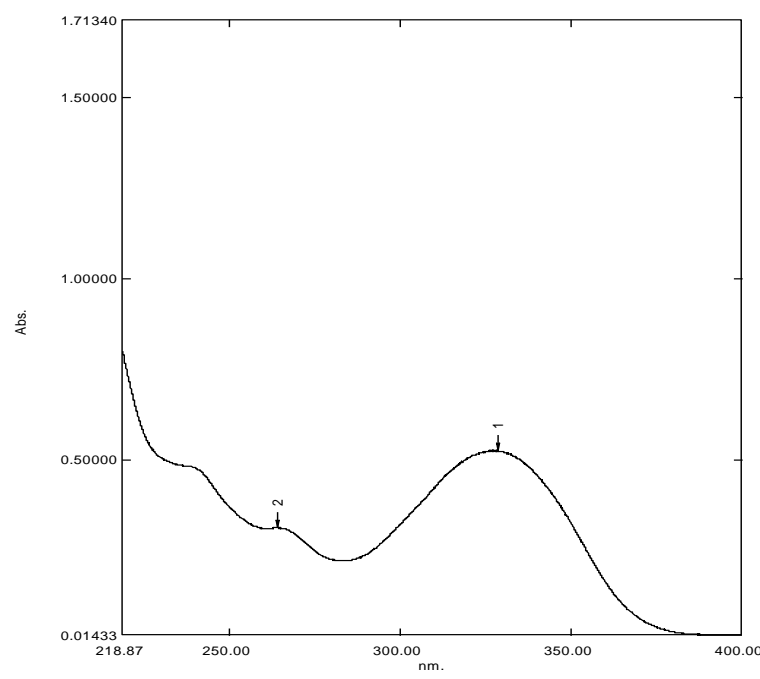

h

Gambar 8. Profil spektrum UV isolat (a) dan standar sinensetin (b)

\section{Kesimpulan}

Senyawa sinensetin dalam tanaman kumis kucing varietas putih dapat diisolasi dengan cara diekstraksi melalui maserasi, ekstraksi cair-cair, kromatografi cair vakum dan kolom gravitasi. Hasil penelitan ini diharapkan dapat menjadi dasar pengembangan produksi sinensetin sebagai suatu senyawa yang berpotensi sebagai anti virus dan imunomodulator.

\section{Ucapan Terima Kasih}

Penelitian ini didanai oleh Kementerian Riset dan Teknologi / Badan Riset dan Inovasi Nasional dengan nomor kontrak 2 / E1 / KP.PTNBH / 2020. 


\section{Deklarasi Konflik Kepentingan}

Semua penulis menyatakan tidak ada konflik kepentingan terhadap naskah ini

\section{Daftar Pustaka}

Adam, Y., Somchit, M. N., Sulaiman, M. R., Nasaruddin, A. A., Zuraini, A., Bustamam, A. A., and Zakaria, Z. A. .2009. Diuretic properties of Orthosiphon stamineus Benth. Journal of Ethnopharmacology 124(1), 154-158. https://doi.org/10.1016/j.jep.2009.04.014

Adem, Ş., Eyupoglu, V., Sarfraz, I., Rasul, A., Zahoor, A. F., Ali, M., Abdalla, M., Ibrahim, I. M., and Elfiky, A. A. 2020. Caffeic Acid Derivatives (CAFDs) as Inhibitors of SARSCoV-2: CAFDs-Based Functional Foods as A Potential Alternative Approach to $\begin{array}{lll}\text { Combat COVID-19. Phytomedicine } & 153310 .\end{array}$ https://doi.org/https://doi.org/10.1016/j.phymed.2020.153310

Adnyana, I. K., Setiawan, F., and Insanu, M. 2013. From Ethnopharmacology to Clinical Study of Orthosiphon stamineus Benth. International Journal of Pharmacy and Pharmaceutical Sciences 5(3).

Anonim. Farmakope Herbal Indonesia (II). 2017. Kementerian Kesehatan RI. Jakarta, 261264.

Arafat, O. M., Tham, S. Y., Sadikun, A., Zhari, I., Haughton, P. J., and Asmawi, M. Z. 2008. Studies on Diuretic and Hypouricemic Effects of Orthosiphon stamineus Methanol Extracts in Rats. Journal of Ethnopharmacology 118(3), 354-360. https://doi.org/10.1016/j.jep.2008.04.015

Astani, A., Reichling, J., and Schnitzler, P. 2011. Screening for Antiviral Activities of Isolated Compounds from Essential Oils. Evidence-Based Complementary and Alternative Medicine 2011, 253643. https://doi.org/10.1093/ecam/nep187

Astani, A., and Schnitzler, P. 2014. Antiviral Activity of Monoterpenes Beta-Pinene and Limonene Against Herpes Simplex Virus In Vitro. Iranian Journal of Microbiology retrieved from internet: https://pubmed.ncbi.nlm.nih.gov/25870747, 6(3), 149-155.

Batubara, I., Komariah, K., Sandrawati, A., and Nurcholis, W. 2020. Genotype Selection for Phytochemical Content And Pharmacological Activities in Ethanol Extracts of Fifteen Types of Orthosiphon aristatus (Blume) Miq. Leaves Using Chemometric Analysis. Scientific Reports 10(1), 1-11. https://doi.org/10.1038/s41598-020-77991-2

Benencia, F., and Courreges, M. 2000. In Vitro and In Vivo Activity of Eugenol on Human Herpesvirus. Phytotherapy Research : PTR 14, 495-500. https://doi.org/10.1002/10991573(200011)14:73.0.CO;2-8

Berim, A., and Gang, D. R. 2016. Methoxylated Flavones: Occurrence, Importance, Biosynthesis. Phytochemistry Reviews Springer Netherlands. https://doi.org/10.1007/s11101-015-9426-0

Bourne, K. Z., Bourne, N., Reising, S. F., and Stanberry, L. R. 1999. Plant Products as Topical Microbicide Candidates: Assessment of In Vitro and In Vivo Activity Against Herpes Simplex Virus Type 2. Antiviral Research 42(3), 219-226. https://doi.org/https://doi.org/10.1016/S0166-3542(99)00020-0

Chang, C.-D., Lin, P.-Y., Hsu, J.-L., and Shih, W.-L. 2016. Ursolic Acid Suppresses Hepatitis B Virus X Protein-mediated Autophagy and Chemotherapeutic Drug Resistance. Anticancer Research 36, 5097-5108. https://doi.org/10.21873/anticanres.11079

Dahab, M. A., Hegazy, M. M., and Abbass, H. S. 2020. Hordatines as a Potential Inhibitor of COVID-19 Main Protease and RNA Polymerase: An In-Silico Approach. Natural Products and Bioprospecting 10(6), 453-462. https://doi.org/10.1007/s13659-02000275-9

Du, Q., and Chen, H. 2010. The Methoxyflavones in Citrus reticulata Blanco Cv. Ponkan and their antiproliferative activity against cancer cells. Food Chem. 119, 567-572. 
doi:10.1016/j.foodchem.2009.06.059

Duan, S.-P., Zhu, L.-H., Li, P., Song, X.-W., Wang, H.-W., and Shen, B.-S. 2016. Effect and Mechanism of Danshensu on Hepatitis B Virus Reverse Transcriptase and Antigen Expression. Zhongguo Zhong Yao Za Zhi = Zhongguo Zhongyao Zazhi = China Journal of Chinese Materia Medica 41, 1297-1301. https://doi.org/10.4268/cjcmm20160722

Faramayuda, F.,Mariani, T. S., Elfahmi and Sukrasno. 2020. Short Communication: Callus Induction in Purple and White-Purple Varieties of Orthosiphon aristatus ( Blume ) Miq. Biodiversitas 21(10), 4967-4972. https://doi.org/10.13057/biodiv/d211063

Faramayuda, F., Mariani, T. S., Elfahmi and Sukrasno. 2021. Tropical Journal of Natural Product Research Potential of Orthosiphon aristatus Blume Miq as Antiviral: A Review. Trop J Nat Prod Res, 5(3):410-419. doi.org/10.26538/tjnpr/v5i3.1

Febjislami, S. .2017. Identifikasi Karakter Morfologi, Argonomi, Kandungan Senyawa Bioaktif dan Tipe Produksi Biji Beberapa Aksesi Tanaman Kumis Kucing (Orthosiphon aristatus (Blume) Miq). Jurnal Hortikultura Indonesia 1-14.

Febjislami, S., Kurniawati, A., Melati, M., and Wahyu, Y. 2019. Morphological Characters, Flowering and Seed Germination of The Indonesian Medicinal Plant Orthosiphon aristatus. Biodiversitas 20, 328-337. https://doi.org/10.13057/biodiv/d200204

Friedman, T. 2015. The Effect of Rosmarinic Acid on Immunological and Neurological Systems: A Basic Science and Clinical Review. Journal of Restorative Medicine 4, 5059. https://doi.org/10.14200/jrm.2015.4.0105

Guo, Z., Liang, X., and Xie, Y. 2019. Qualitative and Quantitative Analysis on The Chemical Constituents in Orthosiphon Stamineus Benth. Using Ultra High-Performance Liquid Chromatography Coupled With Electrospray Ionization Tandem Mass Spectrometry. Journal of Pharmaceutical and Biomedical Analysis 164, 135-147. https://doi.org/10.1016/j.jpba.2018.10.023

Haid, S., Novodomská, A., Gentzsch, J., Grethe, C., Geuenich, S., Bankwitz, D., Chhatwal, P., Jannack, B., Hennebelle, T., Bailleul, F., Keppler, O. T., Poenisch, M., Bartenschlager, R., Hernandez, C., Lemasson, M., Rosenberg, A. R., Wong-Staal, F., Davioud-Charvet, E., and Pietschmann, T. 2012. A Plant-Derived Flavonoid Inhibits Entry of All HCV Genotypes Into Human Hepatocytes. Gastroenterology 143(1), 213 222.e5. https://doi.org/https://doi.org/10.1053/j.gastro.2012.03.036

Halim, N. H., Pauzi, N., Hamil, S. H. R., Shafaei, A., Ismail, Z., and Mohd, K. S. 2017. Standardization of Orthoshiphon stamineus Raw Material and Extracts for Anti-Uterine Fibroid. International Journal of Pharmacognosy and Phytochemical Research 9(4), 512-515.

Harun, N. H., Septama, A. W., and Jantan, I. 2015. Immunomodulatory Effects of Selected Malaysian Plants on The CD18/11a Expression and Phagocytosis Activities of Leukocytes. Asian Pacific Journal of Tropical Biomedicine 5(1), 48-53. https://doi.org/https://doi.org/10.1016/S2221-1691(15)30170-2

Ikeda, K., Tsujimoto, K., Uozaki, M., Nishide, M., Suzuki, Y., Koyama, H., and Yamasaki, H. 2011. Inhibition of Multiplication of Herpes Simplex Virus by Caffeic Acid. International Journal of Molecular Medicine 28, 595-598. https://doi.org/10.3892/ijmm.2011.739

Kashiwada, Y., Wang, H.-K., Nagao, T., Kitanaka, S., Yasuda, I., Fujioka, T., Yamagishi, T., Cosentino, L. M., Kozuka, M., Okabe, H., Ikeshiro, Y., Hu, C.-Q., Yeh, E., and Lee, K.H. 1998. Anti-AIDS Agents. 30. Anti-HIV Activity of Oleanolic Acid, Pomolic Acid, and Structurally Related Triterpenoids. Journal of Natural Products 61(9), 1090-1095. https://doi.org/10.1021/np9800710

Keng, L. C., and Siong, P. L. 2006. Morphological Similarities and Differences between the Two Varieties of Cat's Whiskers ( Orthosiphon stamineus Benth.) grown in Malaysia. International Journal of Botany 2. https://doi.org/10.3923/ijb.2006.1.6 
Kim , H. K., Lee, J., Lee, J. S., Park, Y.-M., and Yoon, T. 2008. Rosmarinic Acid DownRegulates the LPS-Induced Production of Monocyte Chemoattractant Protein-1 (MCP1) and Macrophage Inflammatory Protein-1 alpha (MIP-1 alpha) via the MAPK Pathway in Bone-Marrow Derived Dendritic Cells. Molecules and Cells 26, 583-589.

Kong, L., Li, S., Liao, Q., Zhang, Y., Sun, R., Zhu, X., Zhang, Q., Wang, J., Wu, X., Fang, X., and Zhu, Y. 2013. Oleanolic acid and ursolic acid: Novel Hepatitis C Virus Antivirals That Inhibit NS5B Activity, Antiviral Research 98(1), 44-53. https://doi.org/https://doi.org/10.1016/j.antiviral.2013.02.003

Lin, Z., Neamati, N., Zhao, H., Kiryu, Y., Turpin, J. A., Aberham, C., Strebel, K., Kohn, K., Witvrouw, M., Pannecouque, C., Debyser, Z., De Clercq, E., Rice, W. G., Pommier, Y., and Burke, T. R. 1999. Chicoric Acid Analogues as HIV-1 Integrase Inhibitors. Journal of Medicinal Chemistry 42(8), 1401-1414. https://doi.org/10.1021/jm980531m

Maheswari, C., Maryammal, R., and Venkatanarayanan, R. 2008. Hepatoprotective Activity of "Orthosiphon stamineus" on Liver Damage Caused by Paracetamol in Rats. Jordan J Biol Sci, 1.

Matsubara, T., Bohkagi, T., Watarai, M., Suzuki, H., Ohashi, K., and Shibuya, H. 1999. Antihypertensive Action of Methylripariochromene A from Orthosiphon aristatus, an Indonesian Traditional Medicinal Plant. Chemical Pharmaceutical Bulletin (43), 2091.

Maulana, I., Triatmoko, B., dan Nugraha, A. 2020. Skrining Fitokimia dan Uji Aktivitas Antibakteri Ekstrak dan Fraksi Tanaman Senggugu (Rotheca serrata (L.) Steane \& Mabb.) terhadap Pseudomonas aeruginosa, JPSCR: Journal of Pharmaceutical Science and Clinical Research, 5, 1. https://doi.org/10.20961/jpscr.v5i1.32200

McDougall, B., King, P. J., Wu, B. W., Hostomsky, Z., Reinecke, M. G., and Robinson, W. E. 1998. Dicaffeoylquinic and Dicaffeoyltartaric Acids Are Selective Inhibitors of Human Immunodeficiency Virus Type 1 Integrase. Antimicrobial Agents and Chemotherapy 42(1), 140 LP - 146. https://doi.org/10.1128/AAC.42.1.140

Medini, F., Megdiche, W., Mshvildadze, V., Pichette, A., Legault, J., St-Gelais, A., and Ksouri, R. 2016. Antiviral-Guided Fractionation and Isolation of Phenolic Compounds From Limonium densiflorum Hydroalcoholic Extract. Comptes Rendus Chimie 19(6), 726-732. https://doi.org/https://doi.org/10.1016/j.crci.2016.03.006

Mengoni, F., Lichtner, M., Battinelli, L., Marzi, M., Mastroianni, C., Vullo, V., and Mazzanti, G. 2002. In vitro Anti-HIV Activity of Oleanolic Acid on Infected Human Mononuclear Cells. Planta Medica 68, 111-114. https://doi.org/10.1055/s-2002-20256

Mohamed, E., Pin Lim, C., Saad Ebrika, O., Abdullah, M., Sadikun, A., and Yam, M. (2010): Toxicity Evaluation of A Standardised 50\% Ethanol Extract of Orthosiphon stamineus. Journal of ethnopharmacology 133, 358-363. https://doi.org/10.1016/j.jep.2010.10.008

Muhammad, H., Sulaiman, S. A., Ismail, Z., and Paumgartten, F. J. R. 2013. Study on The Developmental Toxicity Of A Standardized Extract of Orthosiphon stamineus in Rats. Revista Brasileira de Farmacognosia - BrazilianJournal of Pharmacognosy 23(3), 513 520. https://doi.org/10.1590/S0102-695X2013005000039

Nagase, H., Omae, N., Omori, A., Nakagawasai, O., Tadano, T., Yokosuka, A., et al. 2005. Nobiletin and its related flavonoids with Cre-dependent transcriptionstimulating and neuritegenic activities. Biochem. Biophys. Res. Commun. 337, 1330-1336. doi:10.1016/j.bbrc.2005.10.001

Nakanishi, M., Hino, M., Yoshimura, M., Amakura, Y., and Nomoto, H. 2019. Identification of sinensetin and nobiletin as major antitrypanosomal factors in a Citrus cultivar. Exp. Parasitol. 200, 24-29. doi:10.1016/j.exppara.2019.03.008

Narkhede, R. R., Pise, A. V, Cheke, R. S., and Shinde, S. D. 2020. Recognition of Natural Products as Potential Inhibitors of COVID-19 Main Protease (Mpro): In-Silico Evidences. Natural Products and Bioprospecting 10(5), 297-306. https://doi.org/10.1007/s13659-020-00253-1 
Olah, N.-K., Radu, L., Mogosan, C., Hanganu, D., and Gocan, S. 2003. Phytochemical and Pharmacological Studies on Orthosiphon stamineus Benth. (Lamiaceae) Hydroalcoholic Extracts. Journal of Pharmaceutical and Biomedical Analysis 33(1), 117-123. https://doi.org/10.1016/s0731-7085(03)00227-9

Pang, S. F., Yusoff, M., and Gimbun, J. 2014. Extraction and Microencapsulation of Polyphenols from Orthosiphon Stamineus Leaves, Journal Of Mechanical Engineering And Sciences 7, 1033-1041. https://doi.org/10.15282/jmes.7.2014.2.010

Pauzi, N., Mohd, K. S., Hidayah, N., and Halim, A. 2018. Orthosiphon stamineus Extracts Inhibits Proliferation and Induces Apoptosis in Uterine Fibroid Cells. Asian Pacific Journal of Cancer Prevention 19, 2737-2744. https://doi.org/10.22034/APJCP.2018.19.10.2737

Premgamone, A., Sriboonlue, P., Disatapornjaroen, W., Maskasem, S., Sinsupan, N., and Apinives, C. 2001. A Long-Term Study on The Efficacy of A Herbal Plant, Orthosiphon Grandiflorus, and Sodium Potassium Citrate in Renal Calculi Treatment. The Southeast Asian Journal of Tropical Medicine and Public Health 32(3), 654-660.

Ripim, M., Fazil, N., Ibrahim, K., Bahtiar, A., Wai, C., Ibrahim, N., and Nor, M. 2018. Antiviral Properties of Orthosiphon stamineus Aqueous Extract in Herpes Simplex Virus Type 1 Infected Cells. Sains Malaysiana 47(8), 1725-1730.

Rowaiye, Adekunle, Olukemi Onuh, Joy Oladimeji-Salami, Doofan Bur, Moses Njoku, Ifedilichukwu Nma, Comfort John, Olanike Binuyo, and Faith Pius. In silico identification of the potential natural inhibitors of SARS-CoV-2 Guanine-N7 Methyltransferase. ChemRxiv. 2020; 2020:1-39

Savitri, G., Triatmoko, B., and Nugraha, A. 2020. Skrining Fitokimia dan Uji Aktivitas Antibakteri Ekstrak dan Fraksi Tumbuhan Anyang-Anyang (Elaeocarpus grandiflorus J. E. Smith.) terhadap Escherichia coli, JPSCR: Journal of Pharmaceutical Science and Clinical Research, 5, 22. https://doi.org/10.20961/jpscr.v5i1.32206

Sanbongi, C., Takano, H., Osakabe, N., Sasa, N., Natsume, M., Yanagisawa, R., Inoue, K. -., Sadakane, K., Ichinose, T., and Yoshikawa, T. 2004. Rosmarinic Acid in Perilla Extract Inhibits Allergic Inflammation Induced by Mite Allergen, in A Mouse Model. Clinical and Experimental Allergy: Journal of the British Society for Allergy and Clinical Immunology 34, 971-977. https://doi.org/10.1111/j.1365-2222.2004.01979.x

Santosa, D. and P. Haresmita. 2015. Antioxidant Activity Determination Garcinia dulcis (Roxb) Kurz., Blumea mollis (D.Don) Merr., Siegesbeckia orientalis L., and Salvia riparia HBK which collected from Taman Nasional Gunung Merapi Using DPPH (2,2diphenil-1-pikril-hidrazil) and Thin Layer Chromatography'. Majalah Obat Tradisional. doi: $10.22146 /$ tradmedj.7746.

Sarkar, K., and Das, R. 2020. Preliminary Identification of Hamamelitannin and Rosmarinic Acid as COVID-19 Inhibitors Based on Molecular Docking. Letters in Drug Design \& Discovery 17. https://doi.org/10.2174/1570180817999200802032126

Sekiou, O., Bouziane, I., Bouslama, Z., and Djemel, A. 2020. In-Silico Identification of Potent Inhibitors of COVID-19 Main Protease (Mpro) and Angiotensin Converting Enzyme 2 (ACE2) from Natural Products: Quercetin, Hispidulin, and Cirsimaritin Exhibited Better Potential Inhibition than Hydroxy-Chloroquine Against. ChemRxiv. https://doi.org/10.26434/chemrxiv.12181404

Sharifi-Rad, J., Salehi, B., Baghalpour, N., Kobarfard, F., Sharifi-Rad, M., and Mohammadizade, M. 2018. Antiviral Activity of Monoterpenes Thymol, Carvacrol and P-Cymene Against Herpes Simplex Virus In Vitro. International Pharmacy Acta 1(1): 73-73.

Sharma, A. D., and Kaur, I. 2020. Eucalyptol (1,8 cineole) from Eucalyptus Essential Oil A Potential Inhibitor of COVID 19 Corona Virus Infection by Molecular Docking Studies. Preprints 2020030455. (March). https://doi.org/10.20944/preprints202003.0455.v1 
Takano, H., Osakabe, N., Sanbongi, C., Yanagisawa, R., Inoue, K., Yasuda, A., Natsume, M., Baba, S., Ichiishi, E., and Yoshikawa, T. 2004. Extract of Perilla frutescens Enriched for Rosmarinic Acid, a Polyphenolic Phytochemical, Inhibits Seasonal Allergic Rhinoconjunctivitis in Humans. Experimental Biology and Medicine (Maywood, N.J.) 229, 247-254. https://doi.org/10.1177/153537020422900305

Woottisin, S., Hossain, R. Z., Yachantha, C., Sriboonlue, P., Ogawa, Y., and Saito, S. 2011. Effects of Orthosiphon grandiflorus, Hibiscus sabdariffa and Phyllanthus amarus Extracts on Risk Factors for Urinary Calcium Oxalate Stones in Rats. The Journal of Urology 185(1), 323-328. https://doi.org/10.1016/j.juro.2010.09.003

Xu, H.-X., Zeng, F.-Q., Wan, M., and Sim, K.-Y. 1996. Anti-HIV Triterpene Acids from Geum japonicum. Journal of Natural Products 59(7), 643-645. https://doi.org/10.1021/np960165e

Yam, M., Abdullah, M., and Basir, R. 2008. An Investigation of the Anti-Inflammatory and Analgesic Effects of Orthosiphon stamineus Leaf Extract. Journal of medicinal food 11, 362-368. https://doi.org/10.1089/jmf.2006.065

Yam, M., Basir, R., Abdullah, M., and Ismail, Z. 2007. Antioxidant and Hepatoprotective Effects of Orthosiphon stamineus Benth. The American journal of Chinese medicine 35, 115-126. https://doi.org/10.1142/S0192415X07004679

Youn, J., Lee, K., Won, J., Huh, S., Yun, H., and Cho, W. 2003. Beneficial Effects of Rosmarinic Acid on Suppression of Collagen Induced Arthritis. J Rheumatol 30(6). 1203-1207.

Zhang, H.-S., Chen, X.-Y., Wu, T.-C., and Zhang, F.-J. 2014. Tanshinone II A inhibits Tatinduced HIV-1 transactivation through redox-regulated AMPK/Nampt pathway. Journal of Cellular Physiology 229. https://doi.org/10.1002/jcp.24552.

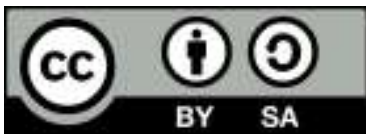

(C) 2021 by the authors. Submitted for possible open access publication under the terms and conditions of the Creative Commons Attribution-ShareAlike 4.0 International (CC BY-SA 4.0) license (https://creativecommons.org/licenses/by-sa/4.0/). 